\title{
CINEGEO
}

International Journal of Environment and Geoinformatics (IJEGEO) is an international, multidisciplinary, peer reviewed, open access journal.

\section{A Study on the Classification of Maritime Security Threat Topics}

\section{Oktay ÇETIN, Mesut Can KÖSEOĞLU}

\author{
Chief in Editor \\ Prof. Dr. Cem Gazioğlu \\ Co-Editors \\ Prof. Dr. Dursun Zafer Şeker, Prof. Dr. Şinasi Kaya, \\ Prof. Dr. Ayşegül Tanık and Assist. Prof. Dr. Volkan Demir
}

Editorial Committee (December 2020)

\begin{abstract}
Assos. Prof. Dr. Abdullah Aksu (TR), Assit. Prof. Dr. Uğur Algancı (TR), Prof. Dr. Bedri Alpar (TR), Prof. Dr. Levent Bat (TR), Prof. Dr. Paul Bates (UK), İrşad Bayırhan (TR), Prof. Dr. Bülent Bayram (TR), Prof. Dr. Luis M. Botana (ES), Prof. Dr. Nuray Çağlar (TR), Prof. Dr. Sukanta Dash (IN), Dr. Soofia T. Elias (UK), Prof. Dr. A. Evren Erginal (TR), Assoc. Prof. Dr. Cüneyt Erenoğlu (TR), Dr. Dieter Fritsch (DE), Prof. Dr. Çiğdem Göksel (TR), Prof.Dr. Lena Halounova (CZ), Prof. Dr. Manik Kalubarme (IN), Dr. Hakan Kaya (TR), Assist. Prof. Dr. Serkan Kükrer (TR), Assoc. Prof. Dr. Maged Marghany (MY), Prof. Dr. Michael Meadows (ZA), Prof. Dr. Nebiye Musaoğlu (TR), Prof. Dr. Masafumi Nakagawa (JP), Prof. Dr. Hasan Özdemir (TR), Prof. Dr. Chryssy Potsiou (GR), Prof. Dr. Erol Sarı (TR), Prof. Dr. Maria Paradiso (IT), Prof. Dr. Petros Patias (GR), Prof. Dr. Elif Sertel (TR), Prof. Dr. Nüket Sivri (TR), Prof. Dr. Füsun Balık Şanlı (TR), Prof. Dr. Uğur Şanlı (TR), Duygu Ülker (TR), Prof. Dr. Seyfettin Taş (TR), Assoc. Prof. Dr. Ömer Suat Taşkın (US), Assist. Prof. Dr. Tuba Ünsal (US), Dr. İnese Varna (LV), Dr. Petra Visser (NL), Prof. Dr. Selma Ünlü (TR), Prof. Dr. Murat Yakar (TR), Assit. Prof. Dr. Sibel Zeki (TR)
\end{abstract}

Abstracting and Indexing: TR DIZIN, DOAJ, Index Copernicus, OAJI, Scientific Indexing Services, International Scientific Indexing, Journal Factor, Google Scholar, Ulrich's Periodicals Directory, WorldCat, DRJI, ResearchBib, SOBIAD 
Reaserch Article

\title{
A Study on the Classification of Maritime Security Threat Topics
}

\author{
Oktay Çetin* iD, Mesut Can Köseoğlu iD \\ Pîrî Reis University, MaritimeFaculty, Maritime Transportation and Engineering Department, 34940 Tuzla -İstanbul, TR \\ * Corresponding author: O. Çetin \\ E-mail: ocetin@pirireis.edu.tr \\ Received 25 Mar 2020 \\ Accepted 13 Oct 2020
}

How to cite: Çetin and Köseoğlu (2020). A study on the classification of maritime security threat topics. International Journal of Environment and Geoinformatics (IJEGEO), 7(3):365-371. DOI: 10.30897/ijegeo.742336

\begin{abstract}
Maritime transportation security can be violated by piracy and terrorist attacks along with a wide variety of threats which may interrupt the free flow of goods through sea lanes of communication. Any disruption of this flow due to threats which may be encountered in international and territorial waters can adversely affect global economy. This paper aims to review the security challenges faced by maritime industry involving risks emanating through marine environment, threats to sustainable maritime economics, mutual international efforts to preserve stability, security in maritime areas of interest to maintain the flow of commodities throughout the World and conventional maritime security risks. Additionally it is aimed to classify the maritime security threat topics considering recent developments in new security concerns, emerging security strategies in the world with a view to its effects on Maritime Economics is emphasized.Issues related to maritime security, which do not yet have an agreed definition in the international arena, are getting more complex day by day. It is thought that it would be appropriate to handle the subject with a holistic approach since it has a comprehensive and unpredictable structure that cannot be limited to The ISPS Code. In conclusion, in this study, threats within the scope of maritime security were classified and it was tried to guide decision makers from an academic perspective.
\end{abstract}

Keywords:Maritime Security, Maritime Strategy, Maritime Security Classification, Maritime Economics.

\section{Introduction}

Maritime security term was established as a kind of perspective to depict sea control from naval point of view during the Cold War times as well as including geopolitical importance. Geopolitical point of view incorporates any risk or utilization of power opposed to the sovereignty, regional integrity or freedom of countries and status of maritime jurisdiction areas. Maritime security have become important as a term after September 11 terrorist attacks in United States of America which can be described as a concept regarding security of marine environment and life, involving maritime regulations, IMO regulations, procedures, measures and operations. This concept has been in discussions since 2002 in an improving popularity in academia. The main reason of this popularity of the maritime security concept can be evaluated by combination of three parameters which are; the terrorists' attacks' impacts in USA in 2002, dramatic terrorist actions against merchant and military navy by Waterborne Improvised Explosive Devices (WBIED) at littorals of Yemen, Red Sea, Bab El Mendeb, and the increase in piracy/armed robbery at sea in the Malacca Strait, Somalia and West Africa littorals since the beginning of the new millennia (Bueger, 2014a). Hence maritime security was acknowledged as preventive measures against illicit exercises at seas and insurance of shipping rather than its geopolitical importance. The attraction of the media to illegal activities led to conscious and measured actions to maintain maritime security and safety at sea. Well-organized governmental and international cohesive actions in the maritime industry aid to establish ship and port security regulations and succeeded in operations against piracy, thereby reducing piracy attacks significantly (Bueger, 2014b; Terzi and Gazioğlu, 2016).

Many of the actors in international arena identify maritime security by defining some of the perils involved in the notion. If the exact expression is different between institutions, the UN Secretary-General's Oceans and Maritime Law Report 2008 provides a summary of the frequently included threats (United Nations, 2008). The report clarifies "armed robbery at sea, piracy, terrorism, illegal human trafficking, smuggling weapons and narcotics, illegal fishing and deliberately and illegally harming the marine environment." The EU and United Kingdom's recent strategy documents provide imitation rules. The UK's 2014 maritime security strategy points out "maritime security risks" instead of perils and brings together various problems. One of these risks is described for example as the "disruption to vital maritime trade routes as a result of war, criminality, piracy or changes in international norms". "Cyberattacks against shipping or maritime infrastructure" is one of these risks included in this strategy document (UK Government, 2014).

A number of costs stemming from the terrorism and various other interruptions to the maritime sectors' sustainability have been approximately calculated and 
noted in economic perspective. Some surveys revealed that terrorist incidents had doubled, and bilateral trade between target economies decreased by 6\% (Nitschand Schumacher, 2003). Another short-term cost category is related to the fluctuations in incertitude on investment decisions and consumer attitude. Incertitude was straight away influenced volatile financial markets. As a result, increasing of insurance costs is a crucial matter, because it brings burden share in increasing premiums to the cost of business transactions. Any kind of maritime terror event would have a significant impact on the cost of marine insurance sector, such as impactful piracy occurrences and, may result in loss of time in shipping operations or prolong shipping period for commodities. These interruptions in the maritime transportation cycle can have worldwide impacts and can deeply affect business trust (Richardson, 2004). The ever-increasing security coverage and improved caution and precautions in airports and seaports costs are high. Extra security checks and inspections cause further time loss in air and border checkpoints. This also adds long-term capital investment on infrastructure and organizational restructuring within governments on top of the burden of carrying out businesses as well as overall competitiveness (Saxton, 2002).

Maritime security is tied directly to environmental and economic concerns in particular. The EU emphasized the importance of this issue in 2007 and demonstrated the Integrated Maritime Policy (IMP) and decided to adopt the "Blue Growth Initiative" five years later (Commission of the European Communities, 2007; European Commission, 2012). Blue Growth is a comprehensive approach that captures the entire marine and maritime sector. This long-term strategy's main purpose is to endorse feasible sea and ocean growth. The EU accepts the marine and maritime environment as stimulating variables for the European economy and has realized that there is a tremendous potential for sustainable economic growth in maritime contribution. The blue economy was projected to garner more than five million employments and a gross added value of around $€ 500$ billion per year (European Commission, 2012).

In this study, it is intended to emphasize maritime economics and maritime security issues by;

- Explaining the importance of maritime security in the light of the geostrategy and sustainable maritime economics activities.

- Classifying the maritime security threat topics considering recent developments in new security concerns.

\section{The Impact of Maritime Security over Maritime Economics System}

Today integrated logistics system is a harmonized body of a series of actions including production and distribution of goods and services. From the economic perspective it implies that commodities have to be shipped with a reasonable pricing to the markets in a timely manner, without any disruption. This requires a well-integrated and well working logistic system to facilitate supply chain processes globally. The modern international transport system includes mainly shipping lanes in the oceans as well as roads, railways, inland waterways, and air freight services. This system has three types. The first part is inter-regional transport, which covers deep-sea shipping and air freight. The second one is short-sea shipping, and often cargoes delivered to the ports by deep sea shipping are transported in short distances. In the third mode cargoes are transported by road, rail, river and canal and this system is called as inland transport. Deep-sea shipping, the most sensitive transport mode for the maritime security, is the sole economic transportation way among the continents for high-volume inter-regional cargoes. Maritime traffic routes are mainly among the major industrial areas of Europe, Asia and North America. As of today the global transportation network is extensively broad that covers thousands of ports and facilities for different types of ships and services with reasonable prices. Compared with the huge amount of maritime cargo, air freight, high speed-high cost transport mode, still accounted for less than $1 \%$ of the volume of goods transported between regions. Among regions short-sea shipping is preferred. This transport mode uses smaller ships ranging generally in size 400 deadweight to 6,000 deadweight tonnes, provides port-to-port service and, the commodities transported to regional centres for instance Hong Kong, Shanghai or Rotterdam viainter-regional transportvessels, is distributed. The inland transport system interfaces with the shipping system through ports and specialist terminals and has an extensive network of roads, railways, and waterways (Stopford, 2009). The combination of these three modes of transport is called multi-modal (or door to door) transport. As a holistic approach modern transport logistics system's aim is to integrate all of these transport systems so that cargo flows smoothly from one part of the system to another. Hence, maritime security is a must for this technologically advanced, time-sensitive, effective, cooperative and competitive and well organized maritime sector.

The nature of maritime trade has a wide regional competition and for its efficiency and security, the continuous development of the maritime supply chain is essential. As a consequence, these natural conditions will continue to affect ports in the world's management strategies (Banomyong, 2005; Yüce and Gazioğlu, 2006). Security is now accepted as one of the necessary preconditions for an effective logistics system for the maritime supply chain, which can provide states with high economic growth. The significance of maritime security leads states to enhance utilization of welldiscussed and carefully planned preventative measures to resolve unexpected events (Dulbecco andLaporte, 2003).

Maritime security in the global logistics system brings additional costs to the maritime sector. This results in higher logistical costs and generally has a negative effect on economic growth. Maritime security enables global trade expansion. It must be taken into consideration that 
the expense of delays and procedures in relation to the international trade is forecasted to be between $5 \%$ and $13 \%$ of the value of the cargoes traded (OECD, 2002). Moreover, subjects relating to maritime security can also become one of the primary drivers of delays unless necessary measures are taken.

Markets in the World have become interwoven in the last two decades. This shows the fact that states are adapting themselves for the strong global winds for the liberalization of trade. These winds arise from internationally accepted trade conventions, along with basically the World Trade Organization (WTO). Other trade groupings such as the European Union, the North American Free Trade Agreement (NAFTA), the Association of South East Asian Nations (ASEAN), Asia Pacific Economic Cooperation (APEC) and the growth of intra-Asian trade are also being developed. These trade policy initiatives have a shared goal: By expediting international trade, they enable new trade opportunities. Trust is the main element among the nations for the trade. That is why global economic integration depends on cost effective and security guaranteed global maritime transportation system. Some trading routes are represented by comparatively less transport operators; operating conditions are less agreeable and potential risks are higher, etc. (Banomyong, 2005). This predicament leads to the failure of these nations to establish and improve their international trade potential, more import prices, less foreign exchange gains from exports, limited expenditure and employability, and thus low financial growth.

The IMO has established standards to improve maritime security on board ships and at ports. But virtually applying security problems to a wide range of the oceans is not simple and has great constraints. In 1 July 2004, under the International Convention Safety of Life At Sea (SOLAS) Chapter XI-2, the International Ship and Port Facility Security Code (ISPS Code) has entered into force and has since built the framework for a wellrounded compulsory security regime for international shipping (IMO, 2012).

Maritime transport represents the main driving forces of international trade and any disruption to the maritime transportation link may severely handicap the international economic system. The requirement for increasing port and marine security around the world has led to the emergence of numerous initiatives from international organizations basically IMO, WCO, ILO, governments, customs, and sometimes private sector (Banomyong, 2005).

Some international organizations have considerably took part in the current maritime security regime's development. Among them, the ISO (International Organization for Standardization) and the WCO are important organizations that have to be referenced. Both of them are crucial factors in encouraging the cohesion and the standardisation of maritime transportation system security needs in the whole trading community. Various standards related to container security (e.g.,
ISO/PAS 28000:2005) has been defined and supply chain security system guidelines has developed by the ISO. These ISO standards can be classified according to their functionalities, in a wide range starting from the basics such as container security to port security and more complex functions such as transportation and supply chain communication security (Banomyong, 2005).

Integrated logistic system, facilitating global supply chain processes and maritime security are homogeneous terms in all over the world. The maritime sea lanes of communication is constantly evolving. Taking this into account, it is necessary to adjust to possible future changes, opportunities and risks to utilize freedom of navigation and maritime trade on the high seas to maximum extent.Inthis context; Arctic Region has become important to many maritime nations because previously non-existing navigational trade routes, notably the "North West Passage", have become navigable due to receding of sea ice for the merchant ships to practice.Regarding impacts of climate change namely global warming will result in these Arctic routes to be open for longer periods throughout the year for the next ten or more years. Therefore global supply chain system will be effective and maybe sustainable in the Arctic region. Thus the new northern passage will also provide an alternative more secure trade route compared to Suez Canal which is subject to many piracy and other unlawful activities.

\section{Literature Review and Methodology}

For merchant navy, the defining concepts for protection of human life, economical structure and environment has been established as "maritime safety" and "maritime security". The concept of safety in maritime transportation peeked in interest after Titanic disaster in April 1912, which led to the adaptation of the International Convention for the Safety of Life at Sea (SOLAS) internationally. Currently SOLAS, which is under the management of IMO, is the fundemental piece in all of maritime transportation industry with International Safety Management (ISM) Code that is incorporated into SOLAS, defining the standards for maritime safety (Solmaz et al., 2020; Cook, 2020).

Security concept in maritime transporation, although is established as a defining concept, has been less commonly emphasized on. The main issue under the subject of maritime security was the states borders and delimitation of sea areas. In 1982, the United Nations Convention of the Law of the Sea (UNCLOS) was opened to nations for signing, providing a legal framework for countries action regarding sea areas and acting as an ocean constitution (UNCLOS 1982;Bernaert 1988; Murphy 2006). The role of UNCLOS as a defining reference for maritime security source from being a legislation that supports countries security in an international equilibrium by requiring countries to establish supportive legislations, in contrast because of countries failing to enact legislations considering security issues and perils of the seas, maritime security 
concept has been devaluing in efficacy (UNCLOS 1982; Cook, 2020).

Maritime security concept is the prevention and absence of threats sourcing from maritime interstate disputes, maritime terrorism, cyber attacks, biological and chemical threats, piracy, human trafficking, smuggling of narcotics and illicit goods, and deliberate environmental harms (Roach, 2004; United Nations, 2008; Vrë,, 2010;KraskaandPedrozo, 2013; Bueger, 2014b, Otto, 2020).

The high level threat piracy presents for international trade has caused maritime industry and international bodies to focus more on security aspect of maritime transportation and improved its presence in policy agendas. On the other hand, interstate disputes such as Arctic area and Eastern Mediterrenean have been increasing attention for establishing more secure sea areas (Bueger, 2014b;Keil, 2014; Cook, 2020; Otto, 2020; Bueger, et al. 2020).

Maritime security is also linked to the international economy considering the economic importance of ocean trade throughout the history. The value of ocean products such as offshore resources, fossil energy, mining and fishing industry commercially has been causing consistent re-evaluation of economic potential of oceans (Bueger, 2014b). From a "maritime economy" point of view, it is clear that confidence and security are essential factors for the decision of making an investment. Obviously, maritime business owners wish to have a stable and secure domain for maritime commerce. In order to establish a viable security at sea, international community, countries and NonGovernmental Organizations (NGOs) need to keep on taking measures to protect the marine environment including fisheries (Stopford, 2009; Bueger, 2014b; Otto, 2020; Silveira, 2020).

In accordance with the Bueger's (2014b) maritime security matrix, the four pillars of maritime security, which are marine environment, economic development, national security and human security, provides the structure for the concept but as the world is getting more and more invested in digitalization, security actors in maritime domain gains variety in the form of cyber security. The increasing reliance on digital technologies also creates vulnerability and exposure for the maritime industry for cyber-attacks. IMO's own Maritime Safety Committee (MSC) has emphasized cyber-security by publishing guidelines for Maritime Cyber Risk Management in 2016, referring to the measures for digital threats causing maritime operation, safety or security releated consequences (MSC, 2016) and introduced Maritime Cyber Risk Management in Safety Management Systems in Resolution MSC.428 (98) to establish cyber security as a part of SOLAS under ISM Code, making cyber security prevention as a mandatory requirement for maritime transportation, creating a more complex concept regarding maritime safety and security (MSC, 2017; Cook, 2020; Silveira, 2020).
With the emerging threat of global warming, although the prediction of consequences is not viable and dynamic, occurance of new sea routes and decreasing economic gains of currently established sea routes creates another actor on security concerns regarding maritime security called climate change (IPCC, 2018; Cook, 2020). The potential difficulties that may occur due to the effects of climate change on maritime security may occur in the form of maritime criminality in coastal communities as stated by IPCC in their $5^{\text {th }}$ Assessment Report (Hoegh-Guldberg et al., 2014; GermondandMazaris, 2019). Considering climates effects on food security and human health, criminal tendencies and maritime criminality on coastal communities has been projected to increase (Cordner, 2010). Climate change's effects on ecological equilibrium also can cause the changes in fish species, endangering the species, which can damage local fishiries causing illegal fishing as well as interstate disputes (Pinsky et al., 2018; GermondandMazaris, 2019). Although subjects focused on unders maritime security varies, environmental concerns such as pollution and climate change is in link with global goals of sustainable development (Gavouneli, 2020).

As emphasized on 2008 UN Secretary General's Report (United Nations, 2008), maritime security has been considered as a transnational mission. Cooperation and coordination of maritime security communities and nations worldwide are the main ideal of the concept of maritime security and maritime stakeholders' securitization.

In this study, utilized methodology is benefiting from a categorized literature review and establishing a basic model for classification of the maritime security threat definitions depending on their importance levels according to "maritime security" literature, international conventions, governing bodies' statements and publications and valuable opinions and evaluations of experts (ship captains and retired navy admirals) in the maritime security field and navy.

For the maritime security classification, actions included in the concept of "maritime security" were grouped and compared with the rose petal model. Considering the literature and expert opinions, a gradation model has been utilized according to the severity and consequences of the grouped actions that may occur regarding human health, economical structure and the environment.

\section{Results and Discussion}

After the painful experiences gained from the sea accidents, the necessary doctrine unity on "maritime safety" has been achieved in the international maritime community. With the addition of the International Safety Management (ISM) Code to SOLAS, "safety" has now established itself as a basic concept in the international maritime industry that requires mandatory measures. It is a well-known fact that strict scrutiny of ISM does not allow the importance of the issue to be loosened. 
"Security", as a new conceptual word compared to safety, emphasizes protection of persons or facilities against threats, unlike "safety". Although satisfactory steps have been taken in terms of international law on "maritime safety" and necessary measures have been taken, it is not yet possible to say the same things for the concept of "maritime security" Despite the fact that IMO, various maritime organizations and academicians are working in the international community, it has not been fully agreed on the scope of the term "maritime security" yet. The aim of this study is to create a discussion platform for decision makers in order to reach a consensus on it. Maritime security related concepts can be considered in different groups according to the size of the effect they will create. In this framework, it is evaluated that a classification can be made as in Table 1 .

Table 1: Classification of the maritime security threat definitions depending on importance levels.

\section{Classification of the Maritime Security Threat Definitions Depending on İmportance Levels}

\section{$1^{\text {st }}$ Grade}

Maritime interstate disputes

Maritime terrorism

\section{Energy, food and resource security}

\section{$2^{\text {nd }}$ Grade}

Security against biological and chemical threat

Smuggling weapons and narcotics
Cyber security and secure information systems $3^{\text {rd }}$ Grade

Illegal fishing

Effects of climate change on maritime security
Illegal human trafficking

Piracy

Armed robbery at sea

Deliberately and illegally harming the marine environment

Definitions used in this gradation system are taken from UN General Assembly Document A/63/63, 2008, Bueger, 2014b and Otto, 2020)

Depending on this gradation we can submit maritime security classification as in Figure 1.

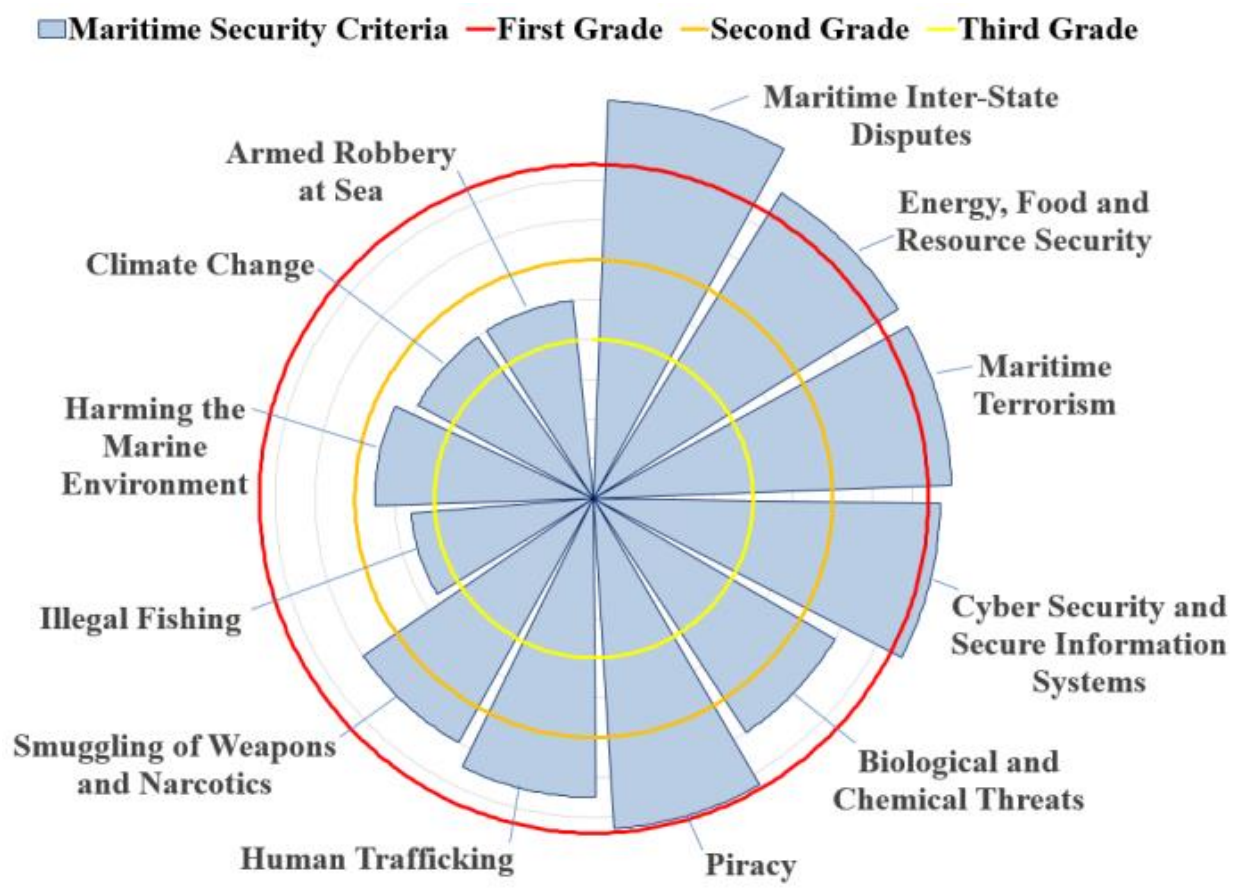

Figure 1. Maritime security classification (Created by authors from various sources)

In Figure 1, it is seen that the title "Maritime interstate disputes" stands out significantly. Dispute of Eastern Mediterranean Sea maritime jurisdiction areas, in August 2020 between Turkey and Greece, created armed conflict risk and perhaps risk of a war.As in this example, considering the possibility of experiencing problems that are difficult to solve diplomatically between countries, "maritime interstate disputes" is considered to be the most important topic. 
On the other hand, considering that $44 \%$ of the commodity transported by sea throughout the world are energy-related products (Stopford, 2009), it is considered that "energy, food and resource security" is one of the most important topics (especially energy security).

Cyber attacks are one of the important risk and threat areas in today's world, where digitalization has gained momentum in technology and significant developments have been experienced in the use of autonomous ships in maritime trade. Therefore"cyber security and secure information systems" carries an important weight in our agenda. The reason why this title is in the first group is the magnitude of the danger that a cyber attack can create if it is carried out in an organized and coordinated manner. In this classification we have created, the importance levels of the titles may differ according to the perspectives of the institutions and individuals. In future academic studies, it will be possible to change the importance levels of the titles by giving numerical values based on concrete data.

\section{Conclusion}

Although it is a term that has come up more frequently as a "buzzword" recently, it has not been possible to define the term maritime security in international relations and to make classifications accordingly. The subject may become more complex with new developments that were not on the agenda before, and sometimes unpredictable and unexpected. For this reason, it is evaluated that the term "maritime security" should be expressed as an internationally recognized definition as it is previously about maritime safety and then necessary steps should be taken regarding the measures to be taken by the authorized institutions and organizations.

The maritime security interests of states extend in a practice involving the projection of security beyond the territorial waters into international waters and perhaps into global maritime areas. Considering the fact that the common interest of humanity should be at the forefront rather than the interests of the countries, it is important to establish the necessary understanding and policies on maritime security in the international arena without delay.

\section{Acknowledgments}

During the meetings held in the process of negotiating and developing the ideas about the article, the valuable ideas and opinions of the retired admiral and navy captains who teach at Piri Reis University were also benefited. We are grateful to participate to these very useful and challenging meetings. In this context, we thank Alp Kenanoğlu, ÖmerAkdağlı, İbrahim Akın and SavaşSefirtürk who contributed to the article.

\section{References}

Banomyong, R. (2005). The impact of port and trade security initiatives on maritime supply-chain management, Maritime Policy and Management, 32.1, 3-13.

Bernaert, A. (1988). Bernaerts' guide to the 1982 United Nations Convention of the Law of the Sea: including the text of the UN Convention and Final Act. Fairplay Publications.

Bueger, C. (2014a). Piracy studies: academic responses to the return of an ancient menace. Cooperation and Conflict, 49(3), 406-416.

Bueger, C. (2014b). What is maritime security? Marine Policy, 53, 159-164.

Bueger, C., Edmunds, T., McCabe, R. (2020). Into the sea: capacity-building innovations and the maritime security challenge. Third World Quarterly, 41(2), 228-246.

Commission of the European Communities (2007). An Integrated Maritime Policy for the European Union,

Cook, P. (2020). Comment: The emerging spectrum of maritime security, International Journal of Maritime Crime and Security (IJMCS), 50-55.

Cordner, L. (2010). Rethinking maritime security in the Indian Ocean Region. Journal of the Indian Ocean Region, 6(1), 67-85.

Dulbecco, P., andLaporte, B. (2003). How can the security of the international supply chain be financed?. Clermont Ferrand, France Centre d'Etudeset de Recherche sur le Development International (CERDI).

European Commission. Directorate-General for Maritime Affairs and Fisheries. (2012). Blue Growth: Opportunities for Marine and Maritime Sustainable Growth: Communication from the Commission to the European Parliament, the Council, the European Economic and Social Committee and the Committee of the Regions. Publications Office of the European Union.

Gavouneli, M. (2020). The Environmental Parameters of Maritime Security: The Case of Energy Installations. Droit de la mer et droits de l'homme: enjeux et perspectives, Liber AmicorumHaritiniDipla,(Pedone, Paris, 2020).

Germond, B., andMazaris, A. D. (2019). Climate change and maritime security. Marine Policy, 99, 262-266.

Hoegh-Guldberg, O., R. Cai, E.S. Poloczanska, P.G. Brewer, S. Sundby, K. Hilmi, V.J. Fabry, and S. Jung (2014). The Ocean. In: Climate Change 2014: Impacts, Adaptation, and Vulnerability. Part B: Regional Aspects. Contribution of Working Group II to the Fifth Assessment Report of the Intergovernmental Panel on Climate Change [Barros, V.R., C.B. Field, D.J. Dokken, M.D. Mastrandrea, K.J. Mach, T.E. Bilir, M. Chatterjee, K.L. Ebi, Y.O. Estrada, R.C. Genova, B. Girma, E.S. Kissel, A.N. Levy, S. MacCracken, P.R. Mastrandrea, and L.L.White (eds.)]. Cambridge University Press, Cambridge, United Kingdom and New York, NY, USA, pp. 1655-1731.

IMO, (2012) The International Ship and Port Facility (ISPS) Code.

IPCC (2018). IPCC special report on the impacts of global warming of $1.5{ }^{\circ} \mathrm{C}$, Summary for Policymakers, 6 October 2018. 
Keil, K. (2014). The Arctic: A new region of conflict? The case of oil and gas. Cooperation and conflict, 49(2), 162-190.

Kraska, J., andPedrozo, R. (2013). International maritime security law. MartinusNijhoff Publishers.

MSC (2016). MSC.1/Circ. 1526, 1 June 2016 Interim Guidelines on Maritime Cyber Risk Management Annex para 1

MSC (2017). IMO Resolution MSC.428 (98).

Murphy, M. (2006). Piracy and UNCLOS: does international law help regional states combat piracy?. In Violence at Sea (167-194). Routledge.

Nitsch, V., and Schumacher, D. (2003). Terrorism and trade (No. 353). DIW Discussion Papers.

OECD, (2002). OECD Economic Outlook. No. 72.

Otto, L. (2020). Introducing Maritime Security: The Sea as a Geostrategic Space. In Global Challenges in Maritime Security (1-11). Springer, Cham.

Pinsky, M. L., Reygondeau, G., Caddell, R., PalaciosAbrantes, J., Spijkers, J., Cheung, W. W. (2018). Preparing ocean governance for species on the move. Science, 360(6394), 1189-1191.

Richardson, M. (2004). Growing Vulnerability of Seaports from Terror Attacks. Yale Global: Viewpoints.

Roach, J. A. (2004). Initiatives to enhance maritime security at sea. Marine Policy, 28(1), 41-66.

Saxton, J. (2002). The economic costs of terrorism. Joint Economic Committee.

Silveira, J. A. (2020). The Evolution of EU's Maritime Security Thinking. In Developments and Advances in Defense and Security (269-280). Springer, Singapore.

Solmaz, M., Erdem, P., Barış, G. (2020). The Effects of Safety Culture on Occupational Accidents: An explanatory study in Container Terminals of Turkey, International Journal of Environment and Geoinformatics, 7(3), 356-364. doi. 10.30897/ijegeo.749735.

Stopford, M. (2009). Maritime Economics Routledge. New York, USA.The ACIA. (2004). Impacts of a Warming Climate: Arctic Climate Impact Assessment. Cambridge: Cambridge University Press.

Terzi, H., Gazioğlu, C. (2016). New Era In Maritime Safety: Safety Culture, 13th International IALA VTS Symposium, International framework for VTS and national regulatory provisions.

UK Government (2014). The UK National Strategy for Maritime Security. UK Government, London, 2014.

UNCLOS (1982). United Nations Convention on the Law of the Sea

United Nations (2008). Oceans and the law of the sea. Report of the Secretary- General, UN General Assembly Document A/63/63, New York.

Vreÿ, F. (2010). African maritime security: a time for good order at sea. Australian Journal of Maritime and Ocean Affairs, 2(4), 121-132.

Yüce H., Gazioğlu C. (2006). Maritime Security Challenges Ahead in the Black Sea, Journal of Black Sea/Mediterranean Environment, Vol.12 (3): 233250. 